\title{
Evaluasi Tiga Prosedur Penyiapan Sampel Daging untuk Deteksi Penyakit Mulut dan Kuku dengan Uji RT-PCR
}

\section{(Evaluation of Three Preparation Procedures for Meat Samples for the Detection of Foot and Mouth Disease by RT-PCR)}

\author{
Nuradji $\mathrm{H}^{1}$, Adjid RMA ${ }^{1}$, Nirmalasanti $\mathrm{N}^{2}$, Khadijah $\mathrm{S}^{2}$, Sekarwati $\mathrm{HD}^{2}$, Widyasari $\mathrm{D}^{2}$ \\ ${ }^{1}$ Balai Besar Penelitian Veteriner, Jl. RE Martadinata No. 30, Bogor 16114 \\ ${ }^{2}$ Balai Besar Karantina Pertanian Tanjung Priuk, Jakarta \\ harimurti.nuradji@gmail.com
}

\begin{abstract}
Foot and Mouth Disease is strategic contagious animal disease and still excotic in Indonesia. The increase of meat demands resulting the importation of meat products from FMD infected country. To anticipate the emergence of this disease, a quick and accurate diagnostic test is required. RT-PCR is a diagnostic test which is recommended by World Animal Health Organization (OIE). However, there is lack of information on the meat preparation procedures for the detection of the disease by RT-PCR. The aim of this study was to evaluate three meat prepration procedures for the detection of FMD by RT-PCR. Meat samples were immersed in synthetic positive control with concentration of 1:1,000 and homogenized by using mortar and pestle, micropestle and syringe. Processed sampels were extracted and tested with RT-PCR. Results indicated that meat samples homogenized by mortar and pestle showing positive results while samples homogenized with micropestle and syringe were negative. This suggests that homogenizaton with mortar and pestle can be used to prepare meat samples for the detection of FMD by using RT-PCR.
\end{abstract}

Key Words: Meat Samples, Preparation Procedures, FMD, RT-PCR

\begin{abstract}
ABSTRAK
Penyakit mulut dan kuku (PMK) merupakan penyakit hewan menular strategis dan masih eksotik di Indonesia. Peningkatan permintaan daging menyebabkan importasi produk daging dari negara yang belum bebas PMK. Untuk mengantisipasi munculnya penyakit ini, uji diagnostik yang cepat dan akurat diperlukan. RT-PCR merupakan uji diagnostik yang direkomendasikan oleh Organisasi Kesehatan Hewan Dunia (OIE). Namun demikian, masih sedikit informasi mengenai prosedur penyiapan sampel daging untuk deteksi penyakit ini dengan RT-PCR. Tujuan dari penelitian ini adalah untuk mengevaluasi tiga prosedur penyiapan sampel daging untuk deteksi PMK dengan uji RT-PCR. Daging dihaluskan dengan menggunakan mortar dan pestle, micropestle dan syringe. Sampel daging yang sudah dihaluskan diekstraksi dan diuji dengan uji RT-PCR. Sebelum dihaluskan sampel daging dimasukkan ke dalam sintetik kontrol positif dengan konsentrasi 1:1.000. Hasil evaluasi menunjukkan bahwa sampel daging yang dihaluskan dengan mortar dan pestle memberikan hasil yang positif sedangkan sampel yang dihaluskan dengan micropestle dan syringe memberikan hasil negatif. Hal ini menunjukkan bahwa penyiapan sampel dengan mortar dan pestle dapat digunakan dalam menyiapkan sampel daging untuk deteksi PMK dengan uji RT-PCR.
\end{abstract}

Kata Kunci: Sampel Daging, Prosedur Penyiapan Sampel, PMK, RT-PCR

\section{PENDAHULUAN}

Penyakit Mulut dan Kuku (PMK) merupakan penyakit yang dapat ditemukan di banyak negara di dunia dan dapat menular dengan sangat cepat, terutama pada hewan berkuku belah (Grubman \& Baxt 2004; Wernery \& Kinne 2012; Jamal \& Belsham 2013). 
PMK disebabkan oleh virus dari genus Aphthovirus, dan famili Picornaviridae (Grubman \& Baxt 2004; OIE 2012; Jamal \& Belsham 2013). Ada tujuh serotipe virus PMK yaitu: O, A, C, Asia 1, SAT 1, SAT 2 dan SAT 3 yang dilaporkan sampai saat ini (Domingo et al. 2002; Davies 2002; Grubman \& Baxt 2004; OIE 2012; Jamal \& Belsham 2013). Sementara itu serotipe C sudah tidak dilaporkan kejadiannya sejak 2004 (Vosloo et al. 2002; Sangula et al. 2011; Brito et al. 2017). Meskipun terdapat tujuh serotipe yang berbeda, gejala klinis yang ditimbulkan sulit untuk dibedakan. Penyakit PMK dapat ditemukan pada sapi, babi, kambing, domba, kerbau dan beberapa hewan liar antara lain rusa, antelope, kangguru (Bhattacharya et al. 2003), gajah (Alexandersen \& Mowat 2005), tapir (Weaver et al. 2013) dan beruang (Officer et al. 2014). Gejala klinis yang muncul bervariasi tergantung galur virus PMK yang menginfeksi hewan tersebut dan pada hewan dewasa umumnya tidak menyebabkan angka kematian yang tinggi (Grubman \& Baxt 2004). Gejala klinis yang terlihat adalah kenaikan suhu tubuh, lemas, nafsu makan turun, dan timbul lepuh lepuh pada mulut dan kuku serta salivasi yang berlebihan (Grubman \& Baxt 2004; Vaccine 2005; Jamal \& Belsham 2013).

Di Indonesia, PMK merupakan salah satu penyakit hewan menular strategis dan masih dinyatakan bebas (Kementan 2013). Walaupun demikian peningkatan kebutuhan daging mendorong Pemerintah Indonesia melakukan pemasukan daging dari negara yang belum bebas PMK seperti India. Penelitian sebelumnya menunjukkan bahwa virus PMK dapat dideteksi dari lidah dan sumsum tulang belakang (Bao et al. 2008) dan limpoglandula (Masana et al. 1995). Virus PMK juga dilaporkan dapat bertahan selama 6 bulan pada suhu $4^{\circ} \mathrm{C}$ di limpoglandula, darah dan sumsum tulang pada sapi yang terinfeksi (Cottral et al. 1960; Cottral 1969). Jaringan tersebut mempunyai potensi dalam menularkan penyakit (Masana et al. 1995). Sehingga perlu dilakukan pengujian daging yang diimpor dari negara yang belum bebas PMK untuk mencegah masuknya penyakit ini di Indonesia.

Uji RT-PCR merupakan salah satu uji yang direkomendasikan dalam pegujian penyakit ini (Reid et al. 2000; Rémond et al. 2002; Alexandersen et al. 2003; OIE 2012). Namun demikian uji ini masih terbatas dilakukan terutama di negara yang bebas PMK seperti Indonesia. Penyiapan sampel terutama daging sangat mempengaruhi hasil dari uji RT-PCR, sehingga perlu dievaluasi untuk memberikan hasil yang optimal. Beberapa penelitian menggunakan mortar dan pestle untuk menghaluskan sampel yang diuji (Wekesa et al. 2015; Shahiduzzaman et al. 2016; Kim et al. 2017), namun demikian mortar dan pestle yang digunakan harus diganti dan disterilisasi setiap melakukan penyiapan sampel untuk menghindari kontaminasi dan penyebaran virus PMK, sehingga prosedur ini membutuhkan waktu yang lebih lama. Berbeda dengan mortar dan pestle, micropestle, merupakan penghalus sampel jaringan yang terbuat dari plastik dan biasanya terdapat dalam kit ekstraksi yang disertakan dalam prosedur ekstraksi sampel organ atau jaringan. Micropestle ini tersedia sesuai dengan jumlah ekstraksi yang tersedia dalam kit tersebut dan bisa langsung digunakan. Sementara itu, syringe digunakan untuk menghaluskan sampel dengan menggunakan stopcock sebagai penghubung. Prosedur ini tidak memerlukan proses sterilisasi karena dapat langsung menggunakan syringe steril. Penelitian ini bertujuan untuk mengevaluasi tiga prosedur penyiapan sampel daging dengan mortar dan pestle, micropestle dan syringe untuk deteksi penyakit mulut dan kuku dengan uji RT-PCR. 


\section{MATERI DAN METODE}

\section{Sampel daging}

Sampel daging diperoleh dari Balai Besar Karantina Pertanian, Tanjung Priok, Jakarta. Sampel daging beku dari produk impor. Daging diuji dengan uji RT-PCR sesuai dengan penelitian sebelumnya (Reid et al. 2000; OIE 2012; Nuradji et al. 2017) untuk memastikan daging tidak mengandung virus PMK.

\section{Kontrol positif}

Sintetik kontrol positif yang digunakan dalam penelitian ini adalah double stranded DNA molekul dengan panjang sekitar 328 bp yang disentesis dengan gBlocks Gene Fragments. Sintetik kontrol positif ini sudah dievaluasi pada penelitian sebelumnya (Nuradji et al. 2017). Penggunaan sintetik kontrol positif dalam penelitian ini karena Indonesia masih bebas penyakit PMK sehingga tidak menyebarkan penyakit ini apabila ada kesalahan di laboratorium.

\section{Prosedur penelitian}

Daging dipotong dan ditimbang dengan berat kurang lebih $25 \mathrm{mg}$. Seperti terlihat pada Tabel 1, sampel daging dibagi tiga kelompok: (a) Kelompok A (mortar dan pestle); (b) Kelompok B (micropestle); dan Kelompok C (syringe). Setiap kelompok terdiri dari 2 daging yang dikontaminasi dengan sintetik kontrol positif dan satu sampel daging yang tidak dikontaminasi dengan sintetik kontrol positif. Kontaminasi daging dilakukan dengan memasukkan daging ke dalam sintetik kontrol positif konsentrasi 1:1000 selama satu jam pada suhu $\pm 25^{\circ} \mathrm{C}$. Sebagai kontrol negatif, sampel daging dimasukkan ke dalam phosphate buffered saline (PBSA) tanpa sintetik kontrol positif selama satu jam pada suhu $\pm 25^{\circ} \mathrm{C}$.

Sampel daging yang dikontaminasi dan tidak dikontaminasi kemudian dihaluskan dengan mortar dan pestle (Kelompok A), micropestle (Kelompok B) dan syringe (Kelompok C). Setelah dihaluskan kemudian sampel divorteks selama 5 detik dan disentrifuge selama 10 menit pada kecepatan 2000 g (OIE 2012). Supernatan kemudian diambil dan diekstraksi serta diuji dengan uji RT-PCR.

Tabel 1. Pembagian kelompok untuk perlakuan sampel daging

\begin{tabular}{lcl}
\hline \hline Kelompok & Sampel daging & \multicolumn{1}{c}{ Perlakuan } \\
\hline A & 1 & Dimasukkan ke dalam PBSA \\
Dihaluskan dengan & 2 & Dimasukkan ke dalam sintetik kontrol positif \\
mortar dan pestle & 3 & Dimasukkan ke dalam sintetik kontrol positif \\
\hline B & 1 & Dimasukkan ke dalam PBSA \\
Dihaluskan dengan & 2 & Dimasukkan ke dalam sintetik kontrol positif \\
micropestle & 3 & Dimasukkan ke dalam sintetik kontrol positif \\
\hline C & 1 & Dimasukkan ke dalam PBSA \\
Dihaluskan dengan & 2 & Dimasukkan ke dalam sintetik kontrol positif \\
Syringe & 3 & Dimasukkan ke dalam sintetik kontrol positif \\
\hline
\end{tabular}




\section{Ekstraksi total RNA}

Total RNA diekstraksi menggunakan geneaid total RNA extraction kit (Geneaid Biotech Ltd., Taiwan) sesuai dengan petunjuk yang ada. Secara singkat, 0,2 ml sampel daging yang dihaluskan ditambahkan ke dalam microfuge tube $0,5 \mathrm{ml}$ yang berisi alkohol $70 \%$ dan $4 \mu \mathrm{l}$ betamercapto ethanol. Sampel kemudian ditambahkan ke dalam reagen Geneaid, dicuci dan RNA dielusi menggunakan $50 \mu 1$ RNAse free water.

\section{Reverse trancription polymerase chain reaction (RT-PCR)}

Uji RT-PCR dilakukan dengan mengikuti prosedur dari Verso 1-Step RT-PCR HotStart Kit (Thermo Fisher Scientific, Inc.) dan penelitian sebelumnya (Nuradji et al. 2017). Secara singkat, $3 \mu \mathrm{RNA}$ virus digunakan sebagai template dalam $20 \mu 1$ reaksi yang mengandung Verso Enzyme Mix, 2X 1-Step PCR Hot-Start Master Mix, RT Enhancer, Primer dan Nuclease Free Water. Primer yang digunakan mengikuti primer dari World Animal Health Organization (OIE)(OIE 2012) dan penelitian sebelumnya (Reid et al. 2000; Lung et al. 2011; Nuradji et al. 2017)

Sintesa cDNA untuk RT-PCR dilakukan dengan inkubasi pada suhu $48^{\circ} \mathrm{C}$ selama 30 menit, diikuti dengan inaktivasi verso pada suhu $94^{\circ} \mathrm{C}$ selama 10 menit. PCR dilakukan dengan 35 siklus yang meliputi: denaturation $\left(94^{\circ} \mathrm{C}\right.$ selama 1 menit), annealing $\left(55^{\circ} \mathrm{C}\right.$ selama 1 menit), extention $\left(72^{\circ} \mathrm{C}\right.$ selama 2 menit). Final extention dilakukan pada suhu $72^{\circ} \mathrm{C}$ selama 7 menit.

Konfirmasi produk RT-PCR dilakukan dengan elektroforesis menggunakan $5 \mu 1$ produk PCR pada $100 \mathrm{~V}$ selama 1 jam pada agarose $1.5 \%$ dalam $1 \times$ Tris Buffer. Visualisasi dilakukan dengan pewarnaan menggunakan Ethidium Bromide dan transluminator ultraviolet.

\section{HASIL DAN PEMBAHASAN}

Beberapa pengujian antara lain isolasi virus, serologi atau RT-PCR telah digunakan untuk mendeteksi PMK (Amaral-Doel et al. 1993; Reid et al. 2000; Grubman \& Baxt 2004; Ma et al. 2011; OIE 2012; Chen et al. 2013). Uji RT-PCR dapat dilakukan lebih cepat dibandingkan dengan uji isolasi virus dan dapat mengurangi resiko penyebaran virus karena kesalahan yang terjadi di laboratorium. Selain itu penelitian sebelumnya menunjukkan bahwa uji RT-PCR lebih sensitif dibandingkan dengan isolasi virus pada sampel probang yang didilusi dengan virus PMK (Amaral-Doel et al. 1993). Uji RT-PCR juga dilaporkan dapat mendeteksi virus PMK pada lidah, sumsum tulang belakang dan nodus limfa (Bao et al. 2008). Pada penelitian ini dilakukan evaluasi tiga prosedur penyiapan sampel daging untuk mendeteksi PMK dengan uji RT-PCR. Tiga prosedur yang dievaluasi dalam penelitian ini merupakan prosedur yang dapat dilakukan di laboratorium.

Sebelum digunakan, daging diuji dengan uji RT-PCR untuk memastikan daging tidak mengandung virus PMK. Hasil uji menunjukkan bahwa daging yang digunakan negatif PMK dengan uji RT-PCR sehingga daging tersebut dapat digunakan dalam penelitian ini. Penyiapan sampel pada pengujian ini dilakukan dengan menggunakan mortar dan pestle sesuai dengan prosedur yang digunakan dalam penelitian sebelumnya (Wekesa et al. 2015; Shahiduzzaman et al. 2016; Kim et al. 2017).

Hasil pada Gambar 1 menunjukkan bahwa hasil positif pada uji RT-PCR hanya ditemukan pada satu sampel daging yang dihaluskan menggunakan mortar dan pestle (Sampel daging 2, Kelompok A) ditandai dengan pita yang terlihat pada 328 bp sesuai dengan kontrol positif yang digunakan. Sementara itu sampel daging yang dihaluskan 
dengan micropestle dan syringe dan semua sampel daging yang hanya dimasukkan ke dalam larutan PBSA menunjukkan hasil negatif. Hal ini menunjukkan bahwa sampel daging yang dihaluskan dengan mortar dan pestle memberikan hasil yang lebih baik dibanding dengan sampel daging yang dihaluskan dengan micropestle dan syringe. Hasil ini mungkin disebabkan proses homogenisasi dengan mortar dan pestle dapat menghaluskan sampel lebih baik dibandingkan dengan menggunakan micropestle dan syringe. Penelitian sebelumnya yang mendeteksi virus PMK pada sampel klinis berupa lidah, nodus limfa (Bao et al. 2008), limpoglandula (Masana et al. 1995) dan jaringan vesikel (Sakamoto et al. 2002) tidak memberikan informasi mengenai prosedur penyiapan sampel yang digunakan. Sementara itu penelitian lain melaporkan bahwa virus dapat terdeteksi pada sampel yang dihaluskan dengan menggunakan mortar dan pestle (Wekesa et al. 2015; Shahiduzzaman et al. 2016; Kim et al. 2017). Hal ini menunjukkan bahwa penyiapan sampel dengan menggunakan mortar dan pestle lebih baik dibandingkan dengan metode lain yang dievaluasi dalam penelitian ini dan dapat digunakan dalam penyiapan sampel daging dalam pengujian RT-PCR.

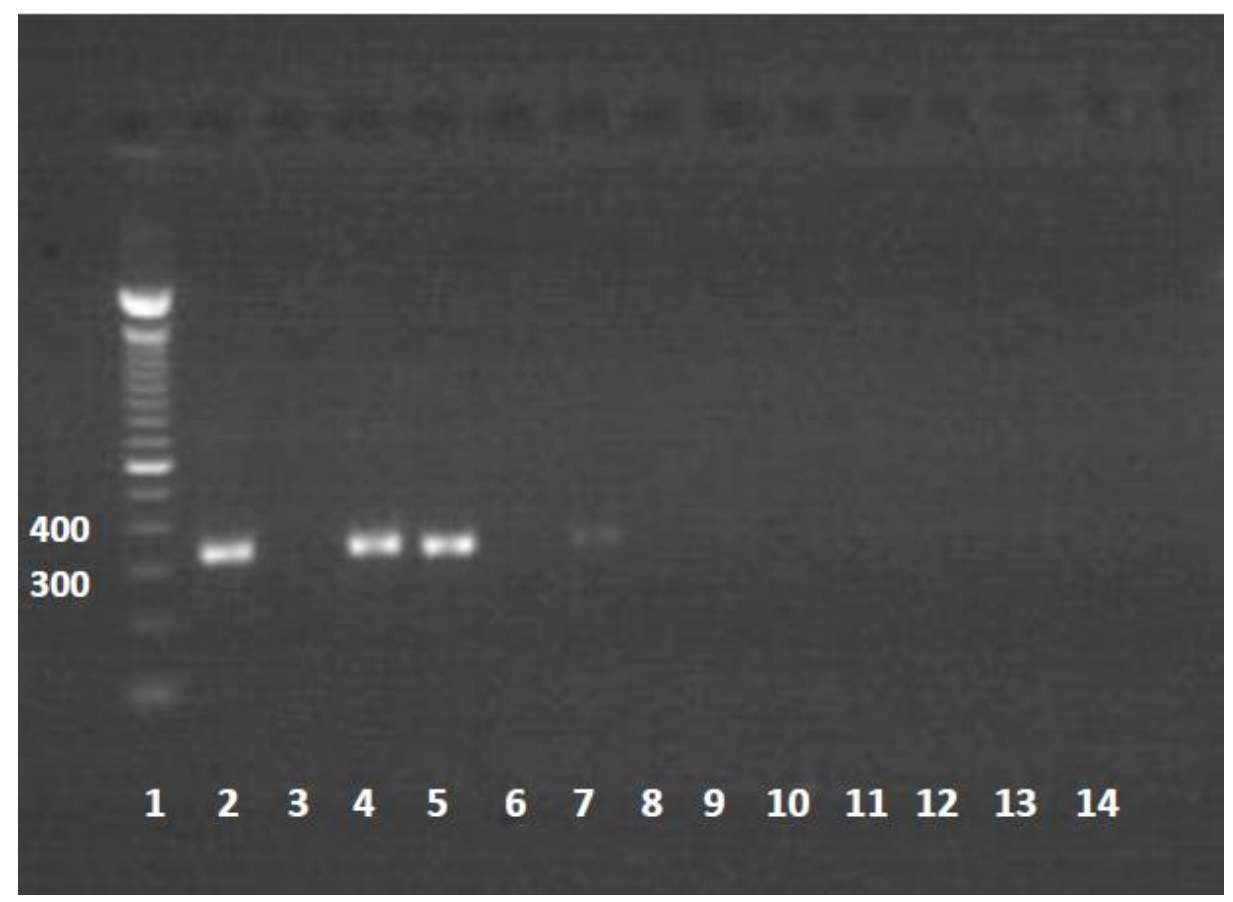

Gambar 1. Analisis produk RT-PCR dengan gel electrophoresis pada sampel daging yang dihaluskan dengan tiga prosedur penyiapan sampel yang berbeda. 1: DNA marker; 2: Kontrol positif; 3: Kontrol negatif; 4: Kontrol positif; 5: Kontrol positif; 6: Sampel daging 1 Kelompok A; 7: Sampel daging 2 Kelompok A; 8: Sampel daging 3 Kelompok A; 9: Sampel daging 1 Kelompok B; 10: Sampel daging 2 Kelompok B; 11: Sampel daging 3 Kelompok B; 12: Sampel daging 1 Kelompok C; 13: Sampel daging 2 Kelompok C; dan 14: Sampel daging 3 Kelompok C

\section{KESIMPULAN}

Evaluasi prosedur penyiapan sampel daging untuk deteksi PMK dengan menggunakan uji RT-PCR memperlihatkan bahwa hanya sampel daging yang dihaluskan dengan mortar dan pestle yang menunjukkan hasil positif. Hal ini menunjukkan bahwa prosedur penyiapan sampel daging dengan mortar dan pestle lebih baik dibandingkan dengan micropestle dan syringe dan dapat digunakan dalam proses penyiapan sampel untuk deteksi PMK dengan uji RT-PCR. 


\section{UCAPAN TERIMA KASIH}

Penelitian ini terlaksana dengan anggaran DIPA BB Litvet tahun 2015-2016. Ucapan terima kasih dan penghargaan disampaikan kepada Agus Winarsongko, Kusmaedi, Ani Purwani, Zulkipli, Apipudin, Masitoh, Hanipah Ariani, Puji, Mansur, Staf di Balai Besar Karantina Pertanian Tanjung Priuk, Jakarta dan semua pihak yang telah membantu dalam pelaksanaan penelitian ini.

\section{DAFTAR PUSTAKA}

Alexandersen S, Mowat N. (2005) Foot-and-mouth disease: Host range and pathogenesis. In: Mahy BW, editor. Foot-and-Mouth Disease Virus. Current Topics in Microbiology and Immunology, vol 288. Berlin (Germany): Springer. p. 9-42.

Alexandersen S, Zhang Z, Donaldson A, Garland AJ. 2003. The Pathogenesis and diagnosis of foot-and-mouth disease. J Comp Pathol. 129:1-36.

Amaral-Doel CMF, Owen NE, Ferris NP, Kitching RP, Doel TR. 1993. Detection of foot-andmouth disease viral sequences in clinical specimens and ethyleneimine-inactivated preparations by the polymerase chain reaction. Vaccine. 11:415-421.

Bao H-F, Li D, Guo J-H, Lu Z-J, Chen Y-L, Liu Z-X, Liu X-T, Xie Q-G. 2008. A highly sensitive and specific multiplex RT-PCR to detect foot-and-mouth disease virus in tissue and food samples. Arch Virol. 153:205-209.

Bhattacharya S, Banerjee R, Ghosh R, Biswas A, Chatterjee A. 2003. Identification of foot-andmouth disease from a captive kangaroo in a zoological garden in India. Vet Rec. 153:504-505.

Brito BP, Rodriguez LL, Hammond JM, Pinto J, Perez AM. 2017. Review of the global distribution of foot-and-mouth disease virus from 2007 to 2014. Transbound Emerg Dis. 64:316-332.

Chen H, Peng Y, Zhang Y, Liu X. 2013. Detection of foot-and-mouth disease serotype O by ELISA using a monoclonal antibody. Monoclon Antib Immunodiagn Immunother. 32:47-49.

Cottral GE. 1969. Persistence of foot-and-mouth disease virus in animals, their products and the environment. Bull Int des épizooties. 71:549-568.

Cottral GE, Cox BF, Baldwin DE. 1960. The survival of foot-and-mouth disease virus in cured and uncured meat. Am J Vet Res. 21:288-297.

Davies G. 2002. Foot and mouth disease. Res Vet Sci. 73:195-199.

Domingo E, Baranowski E, Escarmís C, Sobrino F. 2002. Foot-and-mouth disease virus. Comp Immunol Microbiol Infect Dis. 25:297-308.

Grubman MJ, Baxt B. 2004. Foot-and-mouth disease. Clin Microbiol Rev. 17:465-493.

Jamal SM, Belsham GJ. 2013. Foot-and-mouth disease: past, present and future. Vet Res. 44:1-14.

Kementan. 2013. Keputusan Menteri Pertanian tentang penetapan penyakit hewan menular strategis. Jakarta (Indonesia): Kementerian Pertanian.

Kim S, Kwon H, Park S, Jeon H, Park J, Park J. 2017. Pilot-scale bio-augmented aerobic composting of excavated foot-and-mouth disease carcasses. Sustainability. 9:445.

Lung O, Fisher M, Beeston A, Hughes KB, Clavijo A, Goolia M, Pasick J, Mauro W, Deregt D. 2011. Multiplex RT-PCR detection and microarray typing of vesicular disease viruses. J Virol Methods. 175:236-245.

Ma L, Zhang J, Chen H, Zhou J, Ding Y, Liu Y. 2011. An overview on ELISA techniques for FMD. Virol J. 8:419. 
Masana MO, Fondevila NA, Gallinger MM, Lasta JA, Rodriguez HR, Gonzalez B. 1995. Effect of low-temperature long-time thermal processing of beef-cuts on the survival of foot-and-mouth disease virus. J Food Prot. 58:165-169.

Nuradji H, Wiyono A, Daulay RSD, Rochmah A. 2017. Sintetik Kontrol Positif untuk Deteksi Penyakit Mulut dan Kuku dengan Reverse-Transcription Polymerase Chain Reaction. In: Seminar Nasional Teknologi Peternakan dan Veteriner (In Press).

Officer K, Lan NT, Wicker L, Hoa NT, Weegenaar A, Robinson J, Ryoji Y, Loukopoulos P. 2014. Foot-and-mouth disease in Asiatic black bears (Ursus thibetanus). J Vet Diagn Investig. 26:705-713.

OIE. 2012. Foot and mouth disease. Terr Anim Heal Code [Internet].:1-26. Available from: http://www.oie.int/en/international-standard-setting/terrestrial-code/accessonline/?htmfile=sommaire.htm.

Reid SM, Ferris NP, Hutchings GH, Samuel AR, Knowles NJ. 2000. Primary diagnosis of footand-mouth disease by reverse transcription polymerase chain reaction. J Virol Methods. $89: 167-176$

Rémond M, Kaiser C, Lebreton F. 2002. Diagnosis and screening of foot-and-mouth disease. Comp Immunol Microbiol Infect Dis. 25:309-320. Available from: http://www.sciencedirect.com/science/article/pii/S0147957102000280.

Sakamoto K, Kanno T, Yamakawa M, Yoshida K, Yamazoe R, Murakami Y. 2002. Isolation of foot-and-mouth disease virus from Japanese black cattle in Miyazaki Prefecture, Japan, 2000. J Vet Med Sci. 64:91-94.

Sangula AK, Siegismund HR, Belsham GJ, Balinda SN, Masembe C, Muwanika VB. 2011. Low diversity of foot-and-mouth disease serotype $\mathrm{C}$ virus in Kenya: evidence for probable vaccine strain re-introductions in the field. Epidemiol Infect. 139:189-196.

Shahiduzzaman ANM, Haque ME, Rahman MH, Khan MFR, Rahman MB. 2016. Serotyping and Adaptation of Foot and Mouth Disease Virus in BHK-21 Cell Line towards the Development of Vaccine Candidate. Int J Vaccones Vaccin. 3:1-5.

Vaccine AI. 2005. The FAO-APHCA/OIE Regional Avian Influenza Economic Assessment Workshop PROBLEMS in the implementation of. 2003:81-100.

Vosloo W, Bastos ADS, Sangare O, Hargreaves SK, Thomson GR. 2002. Review of the status and control of foot and mouth disease in Sub-Saharan Africa. Rev Sci Tech Int des épizooties. 21:437-445.

Weaver GV, Domenech J, Thiermann AR, Karesh WB. 2013. Foot and mouth disease: A look from the wild side. J Wildl Dis. 49:759-785.

Wekesa SN, Sangula AK, Belsham GJ, Tjornehoj K, Muwanika VB, Gakuya F, Mijele D, Siegismund HR. 2015. Characterisation of recent foot-and-mouth disease viruses from African buffalo (Syncerus caffer) and cattle in Kenya is consistent with independent virus populations. BMC Vet Res. 11:17.

Wernery U, Kinne J. 2012. Foot and mouth disease and similar virus infections in camelids: a review. Rev Sci Tech. 31:907-918.

\section{DISKUSI}

\section{Pertanyaan}

Apakah sapi yang digunakan dalam penelitian memang sakit PMK, karena Indonesia adalah negara yang bebas PMK? Bila ternak ruminansia diimpor dari Malaysia (yang belum bebas PMK) adakah karantina yang bisa mendeteksi PMK? 


\section{Jawaban}

Ditentukan positif kontrol dibandingkan dengan antigen yang sudah ada. Dalam penelitian ini digunakan gen virus inaktif, jadi tidak digunakan hewan sakit. Di karantina dilakukan pengujian tetapi terbatas. Dijalin kerjasama dengan karantina untuk uji tersebut, untuk menentukan sistem jalan atau tidak diberikan virus inaktif untuk mengujinya 